Ivan Stošić ${ }^{1}$

Ivana Domazet ${ }^{2}$

Sonja Đuričin ${ }^{3}$

Isidora Beraha ${ }^{4}$
JEL: Q42, G10

DOI: 10.5937/industrija45-14609

UDC: 005.52:005.33]:697.34(497.11)

005.52:330.133.1

Case research

\title{
Financial Cost-Benefit Analysis of Investment Possibilities in District Heating System on Wood Residues ${ }^{5}$
}

\author{
Article history: \\ Received: 21 July 2017 \\ Sent for revision: 24 July 2017 \\ Received in revised form: 31 August 2017 \\ Accepted: 31 August 2017 \\ Available online: 10 October 2017
}

\begin{abstract}
The purpose of this research is to provide feasibility analysis of a long-term sustainable development concept for district heating based on wood residues. In this paper, the experimental study has been conducted starting from the data collected by field researches in municipality of Trstenik ( town in Serbia with district heating system currently based on heavy fuel oil and lignite). Using the method of Financial Cost-Benefit Analysis, this study evaluates financial efficiency of investment in district heating plant based on wood residues and energy savings in district heating system. Findings show that such investment could be profitable from the financial point of view: Net Present Value of investment is positive, Financial Rate of Return is high (30.69\%), and the pay-back period is relatively favourable (7 years). Moreover, the presented SWOT indicates that there are realistic prospects of implementation of district heating based on wood residues. However, this does not mean everything will go smoothly and easily, keeping in mind a number of challenges that each new concept of district heating contains immanently. Nevertheless, the results of this research could provide useful inputs for the decision makers when selecting appropriate models for improving performance of municipal district heating systems.
\end{abstract}

\footnotetext{
${ }^{1}$ Institute of Economic Sciences, Belgrade, ivan.stosic@ien.bg.ac.rs

${ }^{2}$ Institute of Economic Sciences, Belgrade

${ }^{3}$ Institute of Economic Sciences, Belgrade

4 Institute of Economic Sciences, Belgrade

${ }^{5}$ This paper is a part of research projects No. 179015 and III 47009 financed by the Ministry of Education, Science and Technological Development of the Republic of Serbia
} 
Stošić I. et al.: Financial Cost-Benefit Analysis of Investment Possibilities in District...

Keywords: Financial Cost-Benefit Analysis; District Heating; Serbia; Biomass; Waste Wood Residues; Economic Sustainability

\title{
Finansijska Cost-Benefit analiza investicija u sistem daljinskog grejanja na drvni otpad
}

\begin{abstract}
Apstrakt: Cilj istraživanja je analiza izvodljivosti dugoročnog održivog koncepta uvođenja sistema daljinskog grejanja koji koristi drvni otpad. Empirijski deo istraživanja u radu je sproveden na osnovu podataka prikupljenih terenskim istraživanjem u opštini Trstenik (grad u Srbiji u kojem je trenutni sistem daljinskog grejanja na mazut i mrki ugalj). Na osnovu metoda Finansijske Cost-Benefit analize, u radu je izvršena ocena finansijske efikasnosti investicije u postrojenje za daljinsko grejanje na drvni otpad $i$ energetsku uštedu u sistemu daljinskog grejanja. Rezultati istraživanja pokazuju da bi ovakva investicija, posmatrano sa finansijskog aspekta, mogla biti profitabilna: Neto sadašnja vrednost investicije je pozitivna, finansijska stopa povraćaja je visoka $(30,69 \%)$ i period povraćaja je relativno povoljan (7. godina). Takođe, prikazana SWOT analiza upućuje na realističnost implementacije sistema daljinskog grejanja na drvni otpad. Primena ovakvog sistema, međutim, ne bi bila jednostavna imajući u vidu da je uvođenje svakog novog koncepta daljinskog grejanja neminovno praćeno brojnim izazovima. Rezultati ovog istraživanja mogli bi da posluže kao veoma korisni inputi donosiocima odluka prilikom odabira odgovarajućih modela za unapređenje performansi sistema daljinskog grejanja u opštinama.
\end{abstract}

Ključne reči: Finansijska Cost-Benefit analiza, daljinsko grejanje, Srbija, biomasa, drvni otpad, ekonomska održivost.

\section{Introduction}

The utilization of energy from biomass waste for the production of heat and power has received much attention in the past decades mainly due to the advances in waste-to-energy technologies, increasing energy prices and the global warming issue (Stehlik, 2009). The use of waste biomass to generate energy can contribute to fuel diversification and to reduce the greenhouse gas (GHG) emissions In this regard, biomass materials such as woody residues are increasingly being recognized as valuable bio resources because they are both renewable and rich in carbon sources (Tsai, 2012).

According to the 2009 Renewables Directive (Directive 2009/28/EC of the European Parliament and of the Council, 2009), the EU will have to reach a $20 \%$ share of energy from renewable sources by 2020 . Its provisions are 
Stošić I. et al.: Financial Cost-Benefit Analysis of Investment Possibilities in District...

compatible with the Kyoto Protocol of the United Nation Framework to Combat Climate Change (1998) and the Paris Agreement (2015), and include increased energy exploitation from the sustainable sources and energy savings which could have indirect positive impact on the technological development, employment and regional development, mainly in less developed areas. Most of the countries intend to replace traditional energy sources with renewable ones including biomass, for many other reasons in addition to the positive impact on climate change (Vojinovic, 2016).

As one of the potential renewable sources of energy and first energy humans ever used, biomass gained importance due to technological progress, potential rise of prices of other energy sources and global warming. There are various biomass types that could be used as a source of energy - agricultural biomass, wood biomass, as well as the urban bio waste and waste from wood industry. Although biomass represents significant energy potential (Djukanovic, 2000), it should be also analysed in the context of potential limitations and social, economic and environmental effects of their exploitation (Nishiguchi \& Tabata, 2016). Biomass materials such as wood residues are becoming internationally recognised as an important source of carbon which could be further used for the production of energy. Around $15 \%$ of the energy needs at the global level is provided from biomass, out of which $13 \%$ in developed countries and $2 \%$ in developing countries (Verani, Sperandio, Picchio, Marchi, Costa, 2015).

According to strategic documents of the International Renewable Energy Agency (IRENA) (International Renewable Energy Agency, 2014), share of the renewable energy sources by 2030 could reach $36 \%$ of the total energy sources. Biomass exploitation is one way to achieve that goal, as in addition to the traditional exploitation referring to heating and cooking it might be useful for industry as well. Data obtained from IRENA indicate that biomass exploitation in manufacturing industry, transport and district heating amounted to $15 \%, 10 \%$ and $8 \%$, respectively (International Renewable Energy Agency, 2014). Due to the fact that waste wood is a low-cost biomass fuel, woody waste has been considered as very attractive for large-scale biomass combustion plants in Serbia (Energy Saving Group and USAID, 2009).

Serbia is energy dependent country which mainly relies on traditional sources of energy such as coal, oil and natural gas. Around two third of the total energy consumption in 2015 was provided from domestic sources, while the rest was imported. The largest share of the domestic production refers to coal, oil and natural gas (two thirds of the total domestic production). The rest is compensated by imports of oil and oil products, natural gas and coal.

In Serbia, providing district heating (DH) services is the responsibility of each municipality and $\mathrm{DH}$ systems are operated by municipal-level publicly owned district heating companies. District heating in Serbia is characterized by its 
Stošić I. et al.: Financial Cost-Benefit Analysis of Investment Possibilities in District...

inefficiency (wasting large amounts of energy), its deteriorating assets (outdated boilers, equipment and devices - boilers average age is up to 30 , network up to 25 and substations average age is up to 25 years), large import dependency on fuels, low asset utilization rates, its high level of air pollution, and the poor quality heating service that it provides to its customers (frequent malfunctions and failures during heating season), lack of funding for savings in energy efficiency and use of renewable energy sources.

Determining prices for the delivered heat energy is not completely liberalized. Prices are determined by the Tariff systems, made by the competent body of the local government, based on the elements prescribed by the Law on Communal Services.

Adding to the high costs of operating heating systems, either for district heating or even standalone systems, is the high cost of heating fuel, particularly heavy fuel oil (mazut) and lignite. This is due to several reasons including monopolistic supply of mazut, and the low productivity level of domestic lignite mines as well as excessive transport costs. In addition, without the proper environmental controls, as is the case for Serbian DH systems, these fuels are highly polluting. As an alternative fuel option, sustainably harvested woody biomass is widely available in Serbia and current fuelwood prices are favourable per unit of energy against current prices of mazut and lignite, but a sustainable increase in supply must be managed. Energy potential of the firewood amounts to 5,410 TJ per year, out of which two thirds are available for heating and the rest for further chemical processing. Estimated energy potential of the forest residues is much higher and it is estimated at about 27,530 TJ / year (llic, 2003).

Given the economic and social aspects, Serbia as a small and energy dependent transition economy could benefit from increased biomass exploitation in several ways. First, reliance on biomass production could replace more expensive energy sources which further could have favourable impact on the balance of payments. Moreover, at the national level, it might increase exports and encourage building of infrastructure (European Climate Foundation, 2010). Second, biomass production could generate additional employment (McKendry, 2002). In Serbian case, this could be particularly important in terms of reducing unemployment in less developed regions as well as more balanced regional development. Third, it could have positive impact through reducing costs of removing excessive biomass generated by the forest industry. Finally, for the local citizens it could be important alternative to the current energy sources providing additional possibility for citizens that are not connected to the grid which could be expensive or technically unfeasible. In that case, it prevents potential energy poverty that, according to the EU Commission, affects around 54 million people in Europe (European Climate Foundation, 2010). For all the aforementioned reasons, 
Stošić I. et al.: Financial Cost-Benefit Analysis of Investment Possibilities in District...

biomass-based district heating as a renewable energy source should be seriously assessed in terms of production possibilities and economic efficiency.

The purpose of this paper is to provide preliminary feasibility analysis of a long-term sustainable development concept for biomass-based district heating for municipalities within Republic of Serbia. The primary objective of this paper is to evaluate the financial efficiency for investment in municipal district heating plant in Serbia, based on Financial Cost-Benefit Analysis as one of key indicators for making investment decisions.

The paper is organized into six sections. In Section 1, the significance of biomass-based district heating for municipalities is analysed, focusing at small, energy-dependent countries such as Serbia. This is followed by the review of relevant studies on different economic and environmental aspects of the use of wood waste biomass for electricity generation and heating in Section 2. The methodology used for the Financial Cost-Benefit Analysis of investment possibilities in municipal $\mathrm{DH}$ plant based on waste wood residues is presented in Section 3, while the information about the biomass heating system in the municipality of Trstenik in Serbia, the proposed solution of a new heating system with financial Cost-Benefit Analysis and a new tariff system are provided in Section 4. The results and implications of using this model of financial Cost-Benefit analysis are given in Section 5, while the concluding remarks and future directions of the authors' research are presented in Section 6.

\section{Literature review}

Many studies have been conducted in order to examine different economic and environmental aspects of the use of wood waste biomass for electricity generation and heating e.g. Akhtari et al. (Akhtari, Sowlati, \& Day, 2014), Schmidt et al. (Schmidt, Leduc, Dotzauer, Kindermann, \& Schmid, 2010), Steubing et al. (Steubing, Zah, \& Ludwig, 2012), Chau et al. (Chau, Sowlati, Sokhansanj, Preto, Melin, \& Bi, 2009), Johnston and Kooten (Johnston \& Kooten, 2015). Groscurth et al. (Groscurth, Almeida, De, Bauen, Costa, \& Ericson, 2000) provided a comprehensive analysis of the economic and environmental performance of the energy use of biomass for selected existing facilities. Lourinho and Brito (Lourinho \& Brito, 2015) stated that the use of biomass residues for energy purposes is attracting more and more attention in recent times as wood wastes in various forms are plentifully available in most of the countries with no other use. However, in many European countries wooden residues are used for pellets production and carbonaceous additives during sewage sludge composting. Morris (Morris, 1999) presented the 
Stošić I. et al.: Financial Cost-Benefit Analysis of Investment Possibilities in District...

environmental and social benefits associated with biomass power production in the United States. They used an analytical approach to compare the impacts of biomass energy production with that of alternative disposal of the residues, as well as of the alternative provision of the energy product. Werner and Erickson (Werner, \& Erickson, 2015) pointed out that more than two thirds of the heat supply to the Swedish district heating systems is nowadays based on biomass and waste resources. These district heating systems provide heat to cover more than half of the heat demands in the Swedish building stock. They revealed the development from the original use of fossil fuels in the late 1970s, the introduction of biomass as fuel in the early 1980s, the transition to considerable more renewables during the 1990s, and to the current situation when biomass dominates the heat supply.

The analysis of cost and benefits was provided within different contexts, e.g. in O'Mahoney et al. (O'Mahoney, Thorne, \& Denny, 2013) a Cost-Benefit Analysis of generating electricity from biomass was conducted considering the long term effects of co-firing with biomass in Irish peat stations. Some of the studies provide economic assessment and financial analysis of the use of wood waste biomass for heating are focused on aspects such as the supply chain ( Whalley, Klein, \& Benjamin, 2017), (Alam, Pulkki, Shahi, \& Upadhyay, 2012), transportation costs (Verani et al., 2015), feasibility of using wood biomass to produce heat (Chau et al., 2009), and potential availability of wood biomass (Macfarlane, 2009). Vallios et al. (Vallios, Tsoutsos, \& Papadakis, 2009) presented a methodology of the design of biomass district heating systems taking into consideration the optimum design of building structure and urban settlement around the plant. Malico et al. (Malico, Carrajola, Gomes, \& Lima, 2016) provided combined assessment of biomass availability, techno economic feasibility and environmental aspects of utilizing forest and agricultural residues to produce bio heat.

In Serbia, only a limited number of studies have examined the possible utilization of wood biomass in the energy system even though the wood residues have significant energy potential given that forests cover about two million hectares, i.e. around one-quarter of the total area of the country (Energy Saving Group and USAID, 2009). In addition, efficiency of forests expressed as the ratio of forest felling and increment, is less than $50 \%$ in Serbia, which is a significant lagging behind in relation to the developed countries where the efficiency of forests is $75 \%$. The condition and development of biomass in general in Serbia is researched by Jovanovic and Parovic (Jovanovic \& Parovic, 2009). Peric et al. (Peric, Komatina, Bugarski, \& Antonijevic, 2016) highlighted the potential benefits of using the "Life Cycle Assessment" tool in energy sector for rational energy consumption with special emphasis on the possibility of practicing this approach in Serbia in terms of proving the environmental suitability of biomass as an energy source (electricity production and heating). Djercan et al. (Djercan, Lukic, Bubalo- 
Stošić I. et al.: Financial Cost-Benefit Analysis of Investment Possibilities in District...

Zivkovic, Djurdjev, Stojisavljevic, \& Pantelic, 2012) provided an overview and an analysis of the possibilities, ecological and economic advantages of utilisation of wood waste as a renewable source of energy and the problems faced by the Serbian producers. Glavonjic et al. (Glavonjic, Pisek, \& Jovic, 2015) defined an adequate methodological concept aimed at obtaining primarily relevant and reliable data on woody biomass potential and consumption. Potential of forest wood in Serbia and the region, the state of the wood processing industry, as well as the possibility of using wood waste were researched in the study previously referred to (Energy Saving Group and USAID, 2009).

The availability, applicability and potential implementation of wood waste biomass as an energy source in a particular municipality or region in Serbia was assessed in a certain number of studies. For example, Janevski et al. (Janevski, Stojanovic, Lakovic, \& Mitrovic, 2016) researched the potential and possibilities of wood biomass in Serbia (with particular reference to the south eastern region of Serbia), which is important for further development of the renewable energy sector. Danon et al. (Danon, Furtula, \& Mandi, 2012) analysed using wood residues from wood industry for CHP (combined heat and power) with an aim to determine the economic feasibility of CHP in Serbia in the light of newly adopted feed in tariffs.

\section{Research methodology}

Investment possibilities in municipal district heating plant based on waste wood residues has been evaluated in this paper from economic aspect by applying Financial Cost-Benefit Analysis (CBA). Namely, the CBA is one of the most widely accepted instruments since it is a rational and systematic decision- making support tool. It is defined as an activity that enables capturing and comparing costs and benefits an investment project might have in a wider or narrower social environment (Djukic, Jovanoski, Munitlak, Lazic, \& Bodroza, 2016). In assessing economic costs and benefits we applied the methodology contained in the European Commission Guide to Cost-Benefit Analysis of investment projects (European Commission, 2014; International Reource Group and USAID, 2012). Financial analysis has been carried out through subsequent, interlinked accounts of 1) total investment costs; 2) sources of financing; 3 ) total operating costs and revenues; 4) calculating economic viability through a net cash flow analysis; 5) calculating Financial Rate of Return on investments (FRR) and financial Net Present Value (NPV).

The key step in the above mentioned analytical process was evaluating the viability by calculation of the financial Net Present Value of the investment (NPV), and the Financial Rate of Return (FRR). More specifically, the financial 
Stošić I. et al.: Financial Cost-Benefit Analysis of Investment Possibilities in District...

Net Present Value and the Financial Rate of Return on the total investment cost, measure the performance of the investment independently of the sources or methods of financing. The financial Net Present Value is defined as value of the discounted net cash flow. Net cash flow was calculated by deducting investment and operating costs of the investment from the expected revenues and applying the following equation (1):

$$
\mathrm{NPV}=\sum_{t=0}^{n} \mathrm{at} \mathrm{S}_{\mathrm{t}}=\frac{\mathrm{S}_{o}}{(1+i)^{0}}+\frac{\mathrm{S}_{1}}{(1+i)^{1}}+\ldots+\frac{\mathrm{S}_{n}}{(1+i)^{\mathrm{n}}}
$$

where $S_{t}$ is the balance of cash flow at time $t, a_{t}$ is the financial discount factor chosen for discounting at time $t$ and $i$ is the financial discount rate. The positive NPV means that the investment project is acceptable; the negative NPV means that it is not acceptable.

The calculation of the Financial Rate of Return on investment measures the capacity of the net revenues to remunerate the investment cost. The Financial Rate of Return is defined as the discount rate that produces a zero NPV, as calculated by equation (2):

$$
0=\sum \frac{\mathrm{S}_{\mathrm{t}}}{(1+\mathrm{FRR})}
$$

The FRR on the other hand is used to judge the future performance of the investment in comparison to other projects, or to a benchmark required rate of return. The FRR represents a relative indicator measuring a project's average profit rate (rate of investments return). The more FRR ends up above the discount factor, or a referent acceptable threshold of the rate of return, the more acceptable and the more attractive project becomes. In principle, if the FRR is below the discounting factor - project is not financially acceptable and the other way around, if it is above it, the project is financially acceptable. Since the FRR may be set at different levels depending on investors' preferences and their readiness to accept a particular rate of return, this criterion is considered to be a selection criterion - its basic purpose is to help investors make the right decision in terms of alternative uses of available capital.

The Financial Cost-Benefit Analysis carried out in this case study has been based on the following assumptions:

- Methodology used for the calculation of financial return is the Discounted Cash Flow (DCF).

- The total investment requirements have been estimated according to authors' research including projections and analysis development plans of 
Stošić I. et al.: Financial Cost-Benefit Analysis of Investment Possibilities in District...

the Municipality of Trstenik, as well as on the basis of previously conducted researches.

- The way of providing the funds for financing was beyond the scope of this analysis and the evaluation of the investment is based on the general assumption that the appropriate investment vehicle could provide financing from its own resources (private equity).

- In order to evaluate acceptability, projections of its annual cash flows have been made and then used to calculate the investment Net Present Value (NPV) and its Financial Rate of Return (FRR). Future costs and revenues flows have been discounted by applying a discounting factor which reflects opportunity costs. The sum of discounted net cash flows (NPV) represents a principle indicator of profitability.

- The financial discount rate (in real term) used is $5 \%$, as recommended by the European Commission for the similar projects in $\mathrm{DH}$ sector.

- The period of projections corresponds to the investment project's reference period, which is 23 years in this case. This period is accepted having in mind that the implementation of the investment will include three years of start up throughout which the investments activities will be finished and then the following 20 years when the business operations will be carried out.

- The prices of the inputs and outputs are considered to be unchangeable during the life cycle of the investment, i.e. the assumption of so called "fixed prices" is introduced. It is also assumed that the relations between the prices of different inputs and outputs will not change during the respective period, so the shares of inputs costs in total are fixed at the starting point level. The prices taken as a starting point in the report are from the beginning of 2013.

- The costs of biomass are calculated by multiplying needed quantity of biomass and its unit price on the basis of available sources of woody biomass in Trstenik area and procuring costs (prices). The maintenance costs are estimated as a percentage of equipment value (3\%).

- Wages are calculated in accordance with the existing ones as the starting point and also with the planned number (based on the principle 1 employee for each 1.3 MW of installed energy capacity) and qualification structure of employees, the expected wage policy and the current labour legislative.

- Costs of electricity (and other material costs) are estimated at $20 \%$ of total expenditures for biomass supply, due to the fact that, apart from biomass, mazut will also be used as a fuel in operating process. 
Stošić I. et al.: Financial Cost-Benefit Analysis of Investment Possibilities in District...

- Various so-called non-material costs which refer to current operations are estimated as $1 \%$ of business revenues.

- Depreciation is calculated based on the value of the fixed assets and the following assumed annual rate of its depreciation: buildings $-1.5 \%$, equipment $-7.0 \%$.

- The financial inflows and outflows are calculated in net prices without VAT and other taxes, except where is mentioned (i.e. taxes and duties on net wages).

- The calculation of effects of energy savings in existing DH systems has been performed within the category of other costs as a negative position due to the fact that these investments should result in the current cost cutting.

- The proposed concept implies the Private Public Partnership (PPP) arrangements where the relationship between public and private sector is based on a shared corporative base in terms of founding and managing the new district heating companies. Furthermore, the concept implies Financial leasing and "Know how fee" as an instrument of financing. The investment funds will be directed to municipal district heating companies based on Financial Leasing model (leasing fee of $12 \%$ on investments in heat-onlyboiler plants, equipment \& building) and the repayment period is 20 years and "Know-how fee" (fee of $20 \%$ on investments in district heating energy savings into existing district heating systems and the repayment period is 20 years).

This quantitative model enables wide application in practice of other cities, as it performs calculations with the key changeable parameters.

\section{Materials}

\subsection{Study Area}

Municipality of Trstenik with area of $448 \mathrm{~km}^{2}$ is located in Central Serbia, in the fertile valley of the West Morava. This area is a home to about 50,000 people in 51 settlements. The city is located on the right bank of the West Morava and has a population of 17,000 inhabitants.

\subsection{Current District Heating System in Trstenik}

District heating is provided by PUC for the production and distribution of thermal energy "Energetika" Trstenik (MDHC Trstenik) 100\% state-owned, established in 2003, as a spin-off of "Prva petoletka" Trstenik. A central boiler 
Stošić I. et al.: Financial Cost-Benefit Analysis of Investment Possibilities in District...

plant is located in the industrial zone of the city that stretches along the main road. The boiler plant was owned by the industry, but it was separated into a dedicated publicly owned district heating company.

The facility is well maintained and still in good condition. The building is of appropriate size with road access and surrounded by plenty of free space making it all together suitable for biomass boiler installation. All substations are standardized, and so is other equipment. It is in good condition while heat distribution management remains very conventional and without appropriate energy efficiency focus.

The company is highly competent but somewhat overstaffed. Due to high costs, company is forced to compromise the quality of service. It lost most of its industrial customers so the available plant is oversized, lacks economy of scale and is forced to operate below its optimal capacity.

Table 1. Trstenik DH System - key data

\begin{tabular}{|lr|}
\hline \multicolumn{1}{|c|}{ Item } & \multicolumn{1}{|c|}{ Data } \\
\hline Avg. length of heating season (days) & 180 \\
\hline Population in City & 17,080 \\
\hline Number of households & 6,376 \\
\hline Number of households connected to SDG & 3,426 \\
\hline Total heating area $\left(\mathrm{m}^{2}\right)$ & 293,263 \\
\hline Total heating area of households connected to SDG $\left(\mathrm{m}^{2}\right)$ & 200,000 \\
\hline Percentage of households connected to system of district heating & $53 \%$ \\
\hline Total heating area of other buildings, institutions and business units $\left(\mathrm{m}^{2}\right)$ & 93,263 \\
\hline Total capacity of heating plant (MWT) & 70.00 \\
\hline Mazut (t/year) & 6,000 \\
\hline Average use of production capacity (\%) & 75.00 \\
\hline Energy consumption (MWht) & 66990 \\
\hline Total length of distribution network (m) & 48,000 \\
\hline
\end{tabular}

Source: Tekon-energy, 2011 and Statistical Office of the Republic of Serbia, 2015.

\subsection{Proposed solution}

The concept of establishing DH system based on waste wood residues in Trstenik is envisaged:

1. Application of advanced heat distribution and heat demand management

2. Use of neglected land and forests

2.1.1. Melioration of coppice forests, thickets and brush-land 
Stošić I. et al.: Financial Cost-Benefit Analysis of Investment Possibilities in District...

2.1.2. Afforestation of selected land areas with fast growing forests

2.1.3. Set up of durable and sustainable forest and land management arrangements to ensure appropriate biomass production

3. Development of biomass fired heat generation plant - Beside two existing boilers currently regularly used, there is a space for a third biomass fired boiler of $10 \mathrm{MWt}$. Furthermore, there is enough space near the plant for biomass chipping, drying and storage. A location near the major road provides necessary transport capabilities. Two existing boilers would remain in service as a reserve and peaking facilities.

Table 2. Planned Intervention in Trstenik DH system - Investment Summary

\begin{tabular}{|l|c|}
\hline \multicolumn{1}{|c|}{ Item } & Data \\
\hline Immediate replacement of substations due to age and condition & $10 \%$ \\
\hline $\begin{array}{l}\text { Immediate replacement of substations - conversion from direct to indirect heat } \\
\text { distribution system }\end{array}$ & 0 \\
\hline $\begin{array}{l}\text { Remaining substations that could be replaced in order to provide better quality } \\
\text { heat distribution and use of Domestic Hot Water (DHW) }\end{array}$ & $90 \%$ \\
\hline Replacement or upgrade of DH network & $10 \%$ \\
\hline $\begin{array}{l}\text { Introduction of advanced substations with preparation of DHW, metering and } \\
\text { remote control }\end{array}$ & yes \\
\hline Introduction of advanced computer based heat distribution management & yes \\
\hline Heat pump envisaged & no \\
\hline New large biomass boiler of 10 MWt capacity (pcs) & 1 \\
\hline Heat storage & yes \\
\hline Option to install backpressure steam turbine and power generator & yes \\
\hline Variable speed drive pumps & yes \\
\hline Biomass shredding machine & yes \\
\hline Covered biomass storage at site & yes \\
\hline Land-space for biomass storage & available \\
\hline Biomass feeding silo & yes \\
\hline Biomass handling equipment required at storage & yes \\
\hline New water treatment plant required & yes \\
\hline
\end{tabular}

Source:Tekon-energy, 2011

4. Establishment of dedicated Energy Saving Company (ESCO) to foster energy efficiency improvement of buildings and its investment plans for all cities listed herein

5. Support introduction of municipal regulation to facilitate production and collection of wooden biomass in urban areas as well as to foster development of high-standing urban vegetation 
Stošić I. et al.: Financial Cost-Benefit Analysis of Investment Possibilities in District...

6. Support to municipal action plans to eradicate energy poverty, introduce more efficient solid fuel stoves and break the link between fuel wood and electricity prices.

7. Use of carbon credits from

7.1. Energy efficiency improvement

7.2. Fuel (mazut, lignite, electricity) replacement

7.3. Reforestation/Afforestation

The development concept envisions specific public private partnership (PPP) agreements with the municipality. The development concept also envisions a limited-term Build-Own-Operate-Transfer (BOOT) agreement between investment vehicle (investor) and municipality for the period of 20 years that will result in establishment of the dedicated new Municipal District Heating Company (MDHC).

Figure 1. Development Concept for the Serbia Biomass District Heating

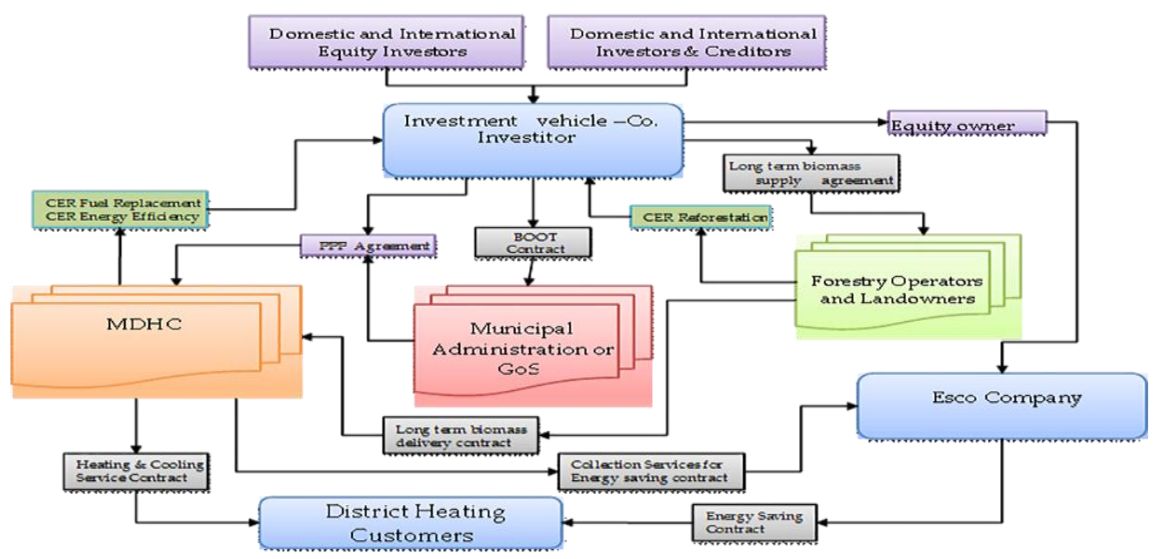

\subsection{Wood Biomass Costs}

The research (Faculty of Forestry University of Belgrade, 2011) showed that the main sources of woody biomass in Serbia are as follows:

- Wood waste from forest cuttings - Wood waste from regular cuttings or thinning of forests owned by the PE Serbia Forests which by its dimensions and quality cannot be sold as technical wood; 
Stošić I. et al.: Financial Cost-Benefit Analysis of Investment Possibilities in District...

- Wood from amelioration process - Total cuts that would occur as an instrument of conversion of the coppice forests, thickets and brush lands into higher growing categories. Additional potential of biomass supply to future heating plants can also be wood from intentionally established intensive plantations with short rotation of a few years;

- $\quad$ Residual wood that comes from wood processing drives - A significant source of raw material for woody biomass may result from primary wood processing drives, which produce a significant percentage of residues in various forms from sawdust to barks and other residues, which can be easily packed and transported to the biomass warehouse in each municipality. A significant advantage of this wood residues refers to its easy accessibility in comparison to wood waste from cuttings;

- Wood biomass from other sources implies wood biomass from: private forests, urban green lands and parks, etc.

Costs of providing biomass out of residual wood after the forest utilization Costs for providing biomass out of residual wood after the use of forests can be divided as follows: residue price, wages for collectors (since the residue is usually all around a forest) and cost of transport to heating plants. According to available data, total biomass residual wood price is estimated to be in Serbia $€ 34$ per ton of air dry wood. The prices of residual wood in Serbia are approximately at a similar level as in some neighbouring countries (Bulgaria $€$ 34 per ton, Romania $€ 30$ per ton, Hungary $€ 28$ per ton), but lower than in the most Western Europe countries (Germany $€ 40$ per ton, Spain $€ 42$ per ton, Italy $€ 37$ per ton, France $€ 35$ per ton, etc.) (Berien, Staritsky, Hengeveld \& Jeurissen., 2014, 54-55).

These residues must be ground in a mechanical grinder located in a warehouse of a heating plant, thus requiring additional costs.

Costs of providing residual wood that comes from wood processing drives Costs of supplying heating plants with residual wood that comes from local wood processing drives can be divided into transport costs regarding sawdust which can be fired directly after drying, while barks need to be ground first. The total cost of sawdust that local wood processing drives sell to factories producing boards and pellets is approximately $€ 3$ per ton, while the cost of transport within $50 \mathrm{~km}$ amounts to around $€ 8$ per ton. Consequently, the total cost of sawdust at plant gate is $€ 11$ per ton, while for barks it is $€ 16$ per ton, what is considerably lower than in most Western Europe countries.

Costs of biomass production from regular cuttings and amelioration - The total costs of biomass production from regular cuttings and amelioration amount to approximately $€ 27$ per ton. Production costs consist of cutting and 
Stošić I. et al.: Financial Cost-Benefit Analysis of Investment Possibilities in District...

pulling costs, transport cost and taxes on cut timber (3\% of timber price on truck road for state forests).

Taking into account the structure of local biomass supply and the prices of specific residues the average price of biomass per ton is estimated at $€ 26.56$. Required and available quantity of biomass in Trstenik area is shown in Table 3.

Table 3. Required and available quantity of biomass wood residues in Trstenik area, in tons

\begin{tabular}{|c|r|r|r|r|r|r|}
\hline $\begin{array}{c}\text { Required } \\
\text { quantity of } \\
\text { biomass }\end{array}$ & $\begin{array}{c}\text { Available } \\
\text { sawdust }\end{array}$ & $\begin{array}{c}\text { Available } \\
\text { sawmill } \\
\text { residue }\end{array}$ & $\begin{array}{c}\text { Available } \\
\text { melioration }\end{array}$ & $\begin{array}{c}\text { Regular } \\
\text { cutting }\end{array}$ & $\begin{array}{c}\text { Forest } \\
\text { residue }\end{array}$ & $\begin{array}{c}\text { Total } \\
\text { Available }\end{array}$ \\
\hline 11,134 & 194 & 454 & 5,979 & 7,108 & 1,309 & 15,044 \\
\hline
\end{tabular}

Source: Authors' calculation based on Faculty of Forestry University of Belgrade, 2011

\subsection{Price formation and tariff rates determination for the calculation of heating energy}

The prices of heating energy and hot-water supply network according to tariff rates and groups are determined in line with the Methodology for heating energy price formation, which is an integral part of the Tariff system, and considering the general pricing policy and municipality (city) district heating substation plans.

According to the above mentioned Methodology, the price of delivered heating energy consists of a variable component and a fixed component. The variable component includes the costs of production and distribution of heating energy and is calculated to the consumer as the price of delivered quantity of heat expressed in RSD/kWh. The fixed component includes the costs of maintenance and operation of the system and is calculated to the consumer as the price of the power output expressed in RSD/kW/year. The energy company may increase the price in case of increase in input prices and if input prices are decreased the company must reduce the price using the formula by which the change in variable or fixed component is calculated. To increase / decrease the price, the energy company must receive an approval from the local self-government authority. The tariffs are different for various groups of consumers: households and others (institutions, producers, trade, etc.). The district heating tariffs (based on 12 months payment) for Trstenik, that are applied in this paper, are $0.749 € / \mathrm{m}^{2}$ for the households (covering heating area of $200,000 \mathrm{~m}^{2}$ ) and $1.872 € / \mathrm{m}^{2}$ for the others (heating area of $93,263 \mathrm{~m}^{2}$ ). For the purpose of analysis, it is assumed that district heating 
Stošić I. et al.: Financial Cost-Benefit Analysis of Investment Possibilities in District...

tariffs will be unchangeable during the life cycle of the investment, i.e. the assumption of so-called "fixed prices".

\section{Results}

The total investment requirements have been estimated to $€ 6.218$ million, or as it follows:

- The total requirements for new DH plant (heat-only-boiler plant equipment \& building) are estimated to $€ 3.349$ million $(€ 2.754$ million in equipment for construction new biomass production plant and $€ 0.595$ million in buildings and others). These investments should be realized during the first three years of the investment life-cycle.

- Considerable heat energy, water and electricity savings needed in order for the heating system to operate would be achieved by investing in energy efficiency improvement of thermal power plants - primary and secondary network rehabilitation, modernization of thermal power plants and substations. The investments in energy savings into $\mathrm{DH}$ existing systems are $€ 2.869$ million. These investments should be realized during the first six years of the investment life-cycle while the largest annual investment (amounting to $€$ 0.982 million occurs in the second year following the beginning of the investment).

The MDHC Trstenik revenues that will be generated from providing the services of district heating from biomass have been estimated on the basis of heating area projections and current average district heating tariff, as well as performances of ESCO in buildings energy savings. For the purpose of the analysis and evaluation, these revenues are the only ones which are taken into account, which means that all other possible revenues coming from noncore businesses of DHC are ignored.

According to afore stated, the projected heating area is supposed to increase from the current $293,263 \mathrm{~m}^{2}$ to $426,419 \mathrm{~m}^{2}$ or by approximately $45 \%$ in total in the entire projection period. Projection of energy consumption with energy savings into existing Trstenik $\mathrm{DH}$ systems and inclusion of the projected changes in $\mathrm{DH}$ area indicates that energy consumption should amount to $40,446 \mathrm{MWh}$ in the $23^{\text {rd }}$ year of the investment life time cycle (in this calculation ESCO energy savings in buildings upgrading are not included). The impact of the planned energy efficiency measures is most evident in the first 4 years, where aggregate energy requirements decrease from 66,990 $\mathrm{MWh}$ to $32,832 \mathrm{MWh}$. Efficiency measures continue to decrease projected energy consumption through year 6 , but thereafter, the planned expansion of the district heating service area surpasses the savings but the increase in 
Stošić I. et al.: Financial Cost-Benefit Analysis of Investment Possibilities in District...

projected energy consumption only grows slowly. Expansion of the district heating service area affecting the efficiency reduction in energy consumption is economically justified in terms of revenues generated from heating services in that period.

The DHC will start to generate the revenues from $\mathrm{DH}$ services after three years of preparation, i.e. after finishing the planned investments (erection of the heating facilities). The total value of the revenues will increase during the investment life time strictly due to the increase in heat supplied (tariffs are assumed constant), so at the beginning of its exploration it will generate around $€ 4.1$ million annually, while at the end of the period it will reach around $€ 5.1$ million (details of operating revenues are provided in Annex).

The total operating costs of MDHC Trstenik vary during the investment life cycle (effects of cost savings have been calculated as a negative position and in some years - when cost reduction, due to energy savings is large, the total operating cost has a negative value). The most important costs items are the costs of biomass purchases, and then depreciation and salaries. Investment will be based on specific financial leasing model (make repayment in the period of 20 years with the leasing fee of $12 \%$ on annual basis for heat-onlyboiler plants- equipment \& building), as well as on making "Know-how fee" (repayment of $20 \%$ on annually basis for investments in energy savings into existing DH systems). Leasing and "Know how fee" annuity (annual paid interest and repayment) are $€ 0.506$ million and $€ 0.589$ million or yearly in total $€ 1.094$ million. The total financial expenses for these purposes during the investment life time are going to be high $-€ 15.250$ million or around $50 \%$ of total revenues (details of costs are provided in Annex).

Presented values of projected income and expenses lead to the conclusion that investment in MDHC Trstenik is economically effective and efficient. Namely, after the first three years of the investment operations, which could be considered as a preparatory phase, MDHC Trstenik will generate considerable gross profits, which will reach range to around $€ 3.6$ million annually at the end of the period. Cash Flow for liquidity calculation of the MDHC Trstenik, described in details in Annex, represents the difference between all inflows and all outflows of the MDHC Trstenik. The MDHC Trstenik will have relatively good liquidity position, but with the oscillations in some years (in the last year of investment life cycle the Cash flows for liquidity of the MDHC Trstenik have significantly positive values due to fact that the residual values are included in that year). It is significant that the total cumulative net cash flow is positive. Positive overall cumulative net cash flow means that investment in MDHC Trstenik is economically justified, which is reflected in an increase in the cash and cash equivalents ensuring the realization of the planned activities with the timely repayment of loans. 
Stošić I. et al.: Financial Cost-Benefit Analysis of Investment Possibilities in District...

Finally, Net Cash Flows of projected MDHC Trstenik Cash Flow are calculated. These cash flows have been formed with the basic goal to evaluate acceptability of the investment from the viewpoint of invested resources. Namely, after discounting the below presented Net Cash Flows the NPV and FRR of the MDHC Trstenik are calculated.

The projections of revenues, total operating costs and gross profits, as well as cash flow for liquidity calculation and Net Cash Flows generated during the investment life time cycle are presented in the following Table 6. (detailed account of the manner of calculating these categories is provided in Annex).

In order to evaluate acceptability of the investment, projections of its annual cash flows have been made and then used to calculate its Net Present Value (NPV) and Financial Rate of Return (FRR). Future costs and revenues flows have been discounted by applying a discounting factor which reflects opportunity costs. The investment will generate the Net Present Value of $€$ 14.133 million, which is indicating the financial viability of the investments as a whole.

Table 4. Revenues, total operating costs, gross profits, cash flow for liquidity calculation and Net Cash Flows of MDHC Trstenik (in €)

\begin{tabular}{|c|r|r|r|r|r|}
\hline Years & $\begin{array}{r}\text { Projection of } \\
\text { the revenues }\end{array}$ & $\begin{array}{c}\text { Projection of } \\
\text { the operating } \\
\text { cost }\end{array}$ & $\begin{array}{c}\text { Income } \\
\text { statement - } \\
\text { Gross Profit }\end{array}$ & $\begin{array}{c}\text { Cash flow for } \\
\text { liquidity } \\
\text { calculation }\end{array}$ & $\begin{array}{c}\text { Cash flow for } \\
\text { NPV and } \\
\text { FRR } \\
\text { calculation }\end{array}$ \\
\hline 1 & 0 & 2,433 & $-2,433$ & -730 & $-25,199$ \\
\hline 2 & 0 & 9,032 & $-9,032$ & 61,428 & $-926,55$ \\
\hline 3 & 0 & $-125,742$ & 125,742 & 340,323 & $-3,598,316$ \\
\hline 4 & $4,066,764$ & $1,314,564$ & $1,725,186$ & 662,565 & 962,575 \\
\hline 5 & $4,250,077$ & $1,354,805$ & $1,877,622$ & 717,654 & $1,362,860$ \\
\hline 10 & $4,814,935$ & $1,460,242$ & $2,409,247$ & 793,011 & $1,887,813$ \\
\hline 15 & $4,943,058$ & $1,474,093$ & $2,670,690$ & 704,552 & 704,552 \\
\hline 20 & $5,131,281$ & $1,492,954$ & $3,148,997$ & 500,714 & 500,714 \\
\hline 23 & $5,297,724$ & $1,508,662$ & $3,636,694$ & $1,185,363$ & $1,185,363$ \\
\hline
\end{tabular}

Source: Authors calculation

The pay-back period, as an important indicator of investment viability, is rather favourable and is 7 years. Last, but not least, the viability of the investments is also confirmed through the values of the Financial Rate of Return. The investment could expect to have FRR of $30.69 \%$ or over the discounting rate, i.e. over the threshold which represents the opportunity costs for the invested funds. Obtained rates of return in general could be considered as favourable ones, particularly since this is an infrastructure investment which, as any other investment of its kind, does not yield high direct returns. 
Stošić I. et al.: Financial Cost-Benefit Analysis of Investment Possibilities in District...

The projections of revenues, total operating costs and gross profits, as well as cash flow for liquidity calculation and Net Cash Flows generated during the investment life time cycle are presented in the following Table 4. (detailed account of the manner of calculating these categories is provided in Annex).

Table 5. SWOT analysis of the proposed investment

\begin{tabular}{|c|c|c|}
\hline & Strengths & Weaknesses \\
\hline- & $\begin{array}{l}\text { Sustainable and competitive heating } \\
\text { services and increase in the quality of } \\
\text { DH services } \\
\text { Extensive availability of woody biomass } \\
\text { resources at reasonable prices } \\
\text { Development concept fully in line with } \\
\text { the laws and strategies of the Republic } \\
\text { of Serbia and EU policy to meet } \\
20 / 20 / 20 \text { targets } \\
\text { Financial viability and sustainability of } \\
\text { the development concept } \\
\text { Relatively lower DH bills and no feed in } \\
\text { tariffs in place } \\
\text { Elimination of the extensive and } \\
\text { unsustainable municipal } \\
\text { expenditures to support DH systems } \\
\text { functioning and mounting } \\
\text { Creation of new long term local jobs in } \\
\text { woody biomass supply sector, additional } \\
\text { income to local forestry owners and } \\
\text { contractors }\end{array}$ & $\begin{array}{ll}- & \text { Capital intensive concept } \\
\text { - } & \text { Lack of effective support mechanism } \\
\text { for development of biomass sector } \\
\text { - } \quad \text { Low local know-how in production of } \\
\text { thermal energy from woody biomass } \\
\text { - } \quad \text { Insufficient locally available know-how } \\
\text { - } \quad \text { Production of equipment in the country }\end{array}$ \\
\hline & Opportunities & Threats \\
\hline - & $\begin{array}{l}\text { Massive re-powering of existing } \mathrm{DH} \\
\text { systems } \\
\text { Introduction of new more efficient and } \\
\text { environmentally friendly technologies } \\
\text { Meet up the growing demand } \\
\text { Economic viability - creation of new long } \\
\text { term local jobs, additional income to } \\
\text { local forestry owners and contractors, } \\
\text { increased market value for local land } \\
\text { and more public revenues to local } \\
\text { budgets }\end{array}$ & 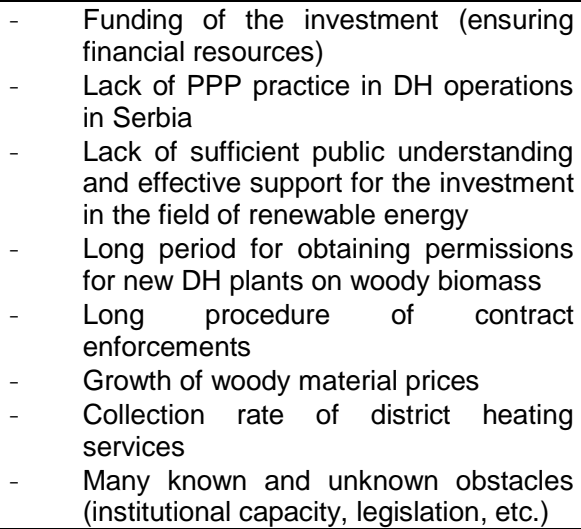 \\
\hline
\end{tabular}

Source: Authors' analysis

Furthermore, sensitivity analysis tests, in order to evaluate the impact of changes in key Project parameters to the overall project viability, has been conducted. Three key Project parameters were explored: total revenues, 
Stošić I. et al.: Financial Cost-Benefit Analysis of Investment Possibilities in District...

operational costs and investment costs. The maximum degree of parameter change tested is $20 \%$ up and down. This is considered sufficient to cover all important unexpected situations in real life circumstances. It could be said that the Project is the most sensitive to changes of revenues, while it is less sensitive to investments changes and it is almost not sensitive to changes of business expenses.

As demonstrated by previous analysis, the Net Present Value and the Financial Rate of Return are favourable and that assures, from a financial point of view, the viability of the investment. Consequently, the use of wood biomass in Trstenik DH system may be a valid alternative to the conventional heating based on mazut.

The challenges and expected outcomes following the realisation of the investment in biomass-based district heating could be summarized through a SWOT analysis (Table 5), i.e. strengths and weaknesses of the proposed concept and its implementation possibilities, as well as opportunities and threats (limitations).

The constellation of strengths and weaknesses, and opportunities and threats, indicates that there are realistic prospects of implementation of $\mathrm{DH}$ based on wood residues. Consequently, this does not mean that everything will go smoothly and easily, keeping in mind above all a number of issues that this concept contains immanently.

\section{Conclusions}

The utilization of biomass for heating is currently regarded as a renewable energy source with a high growth potential. Namely, an introduction of biomass heating systems may bring mutual economic and ecological benefits. From an ecological point of view, the advantages are associated with biomass that do not contain sulphur dioxide and therefore reduce pollutant emissions (environmentally friendly solution). From an economic point of view, the advantages refer to reducing energy import dependence and intensification of economic development through a reduction of unemployment in areas rich in plant biomass, which are usually underdeveloped and with a high unemployment rate. One of the sources of biomass for district heating are wood residues and their application for this purpose in Serbia, mainly from the economic point of view, was in the centre of research.

To be precise, the research in this study is focused on financial attractiveness of investment in district heating plant based on wood residues and energy savings in district heating system by using the method of financial cost-benefit analysis, as one of key tools for making investment decisions. 
Stošić I. et al.: Financial Cost-Benefit Analysis of Investment Possibilities in District...

Financial cost-benefit analysis is conducted starting from the data collected by field researches in municipality of Trstenik (small town in Serbia with district heating system currently based on heavy fuel oil and lignite), founded on the specific total amount of investment, projected revenues and costs and by taking into consideration the sources of financing grounded on Build-OwnOperate-Transfer (BOOT) agreement.

The key results of the analysis show: a) the investment is generating a Net Present Value in the amount of $€ 14.133$ million, so it could be concluded that the investment could be financially very attractive; b) the investment is generating a Financial Rate of Return (FRR) of $30.69 \%$ which exceeds the discount rate and is considered high. The high value of FRR indicates that the investment is financially viable, and c) the period of time required to recover the cost of an investment is 7 years.

These results of research highlight the financial sustainability in the district heating system based on wood residues. In spite of the high value of required initial investment relative to the size of the Municipality of Trstenik, this investment is profitable on long term. Consequently, investments in implementing such municipal DH systems can be considered as successful and financially viable. Moreover, the presented SWOT (analysis strengths and weaknesses as well as the opportunities and threats of proposed concept and its implementation possibilities) indicates that there are realistic prospects of implementation district heating based on wood residues. However, this does not mean that everything will go smoothly and easily, keeping in mind a number of challenges that each new concept of district heating contains immanently.

The development of future district heating projects based on wood residues will inevitably depend on capability to bridge financing barriers usually manifesting in large investment costs and organization of forest biomass provision. Many European countries (most of all Sweden and Finland), unlike Serbia, are relying on wood residues in DH systems. As though Europe is moving in the field of $\mathrm{DH}$ toward renewable energy sources, Serbia will have to follow the same path.

The authors believe that this paper provides useful inputs for the decision makers when selecting appropriate models for improving performance of municipal DH systems. Since financial cost-benefit analysis is only one part of the overall investment analysis, an exhaustive economic analysis is required in order to provide more complete and comprehensive results. In light of that, as a final point, we propose that future research, a part of energy and environmental impact analysis, include an economic and financial analysis of investment in municipal district heating systems by setting local values to the parameters into the model presented in this paper. 
Stošić I. et al.: Financial Cost-Benefit Analysis of Investment Possibilities in District...

\section{References}

Akhtari, S., Sowlati, T., \& Day, K. (2014). The effects of variations in supply accessibility and amount on the economics of using regional forest biomass for generating district heat. Energy, 67, 631-640. doi:10.1016/j.energy.2014.01.092.

Alam, B., Pulkki, R., Shahi, C., \& Upadhyay, T. (2012). Modeling Woody Biomass Procurement for Bioenergy Production at the Atikokan Generating Station in Northwestern Ontario. Canada. Energies, 5, 5065-5085. doi:10.3390/en5125065.

Elbersen, B., Staritsky, I., Hengeveld, G., \& Jeurissen, L. (2014). Outlook of spatial biomass value chains in EU28, Intelligent Enery Europe.

Chau, J., Sowlati, T., Sokhansanj, S., Preto, F., Melin, S., \& Bi, X. (2009). Economic sensitivity of wood biomass utilization for greenhouse heating application. Appl. Energy, 86, 616-621. doi:10.1016/j.apenergy.2008.11.005.

Danon, G., Furtula, M., \& Mandi, M. (2012). Possibilities of implementation of CHP (combined heat and power) in the wood industry in Serbia. Energy, 48, 169-176. doi:10.1016/j.energy.2012.02.073.

Directive 2009/28/EC of the European Parliament and of the Council. Off. J. Eur. Union, (2009). 140(16), 16-62.

Djukanovic, S. (2000). Društveni troškovi energetike zasnovane na eksploataciji uglja. Industrija, 26(1-4), 63-82.

Djukic, M., Jovanoski, I., Munitlak, O., Lazic, M., \& Bodroza, D. (2016). Cost-benefit analysis of an infrastructure project and a cost-reflective tariff : A case study for investment in wastewater treatment plant in Serbia. Renew. Sustain. Energy Rev., 59, 1419-1425. doi:10.1016/j.rser.2016.01.050.

Djercan, B., Lukic, T., Bubalo-Zivkovic, M., Djurdjev, B., Stojisavljevic, R., \& Pantelic, M. (2012). Possibility of efficient utilization of wood waste as a renewable energy resource in Serbia. Renew. Sustain. Energy Rev., 16, 1516-1527. doi:10.1016/j.rser.2011.10.017.

-Energy Saving Group, , \& -USAID, (2009). Feasibility Study: Wood waste utilization in Serbia.

-European Climate Foundation. (2010). Biomass for heat and power.

-European Commission. (2014). Guide to Cost-Benefit Analysis of Investment Projects. doi:10.2776/97516.

-University of Belgrade, Faculty of Forestry. (2011). Biomass cost and availability study.

Glavonjic, B., Pisek, R., \& Jovic, D. (2015). Spatial wood fuels production and consumption analysis, The work carried out in the framework of the FAO/Government of Serbia Project: "Wood energy for sustainable rural development" TCP/YUG/3201.

Groscurth, H., de Almeida, A., Bauen, A., Costa, F.B., \& Ericson, S. (2000). Total costs and benefits of biomass in selected regions of the European Union. Energy, 25, 1081-1095.

Ilic, M. (2003). Energetski potencijal i karakteristike ostataka biomase i tehnologije za njenu pripremu i energetsko iskoriscenje u Srbiji.

-International Renewable Energy Agency. (2014). Global Bioenergy Supply and Demand Projections. 
Stošić I. et al.: Financial Cost-Benefit Analysis of Investment Possibilities in District...

-International Reource Group, , \& -USAID, (2012). Prefeasibility Assessment of Biomass District Heating Application in Serbia: Final Report.

Janevski, J.N., Stojanovic, B.V., Lakovic, M.S., Mirko, M., \& Mitrovic, D.M. (2016). Wood biomass in Serbia: Resources and possibilities of use. Energy Sources, Part B Econ. Planning, Policy, 11, 732-738. doi:10.1080/15567249.2013.791897.

Johnston, C.M.T., \& Van. Kooten, G.C. (2015). Economics of co-firing coal and biomass: An application to Western Canada. Energy Econ., 48, 7-17. doi:10.1016/j.eneco.2014.11.015.

Jovanovic, B., \& Parovic, M. (2009). Stanje i razvoj biomase u Srbiji.

Law on Comunal Services. Off. Gaz. Repub. Serbia, (2011). [WWW Document], n.d., 88/2011 104/2016. Retrieved from http://www.paragraf.rs/propisi/zakon_o_komunalnim delatnostima.html

Lourinho, G., \& Brito, P. (2015). Assessment of biomass energy potential in a region of Portugal (Alto Alentejo). Energy, 81, 189-201. doi:10.1016/j.energy.2014.12.021.

Macfarlane, D.W. (2009). Potential availability of urban wood biomass in Michigan: Implications for energy production, carbon sequestration and sustainable forest management in the U. S. A. Biomass and Bioenergy, 33, 628-634. doi:10.1016/j.biombioe.2008.10.004.

Malico, I., Carrajola, J., Gomes, C.P., \& Lima, J.C. (2016). Biomass residues for energy production and habitat preservation. Case study in a montado area in Southwestern Europe. J. Clean. Prod., 112, 3676-3683. doi:10.1016/j.jclepro.2015.07.131.

McKendry, P. (2002). Energy production from biomass (Part 1): Overview of biomass. Bioresour. Technol., 83(1), 37-46. pmid:12058829. doi:10.1016/S09608524(01)00118-3

Morris, G. (1999). The Value of the Benefits of U. S. Biomass Power.

Nishiguchi, S., \& Tabata, T. (2016). Assessment of social, economic, and environmental aspects of woody biomass energy utilization: Direct burning and wood pellets. Renew. Sustain. Energy Rev., 57, 1279-1286. doi:10.1016/j.rser.2015.12.213.

O'mahoney, A., Thorne, F., \& Denny, E. (2013). A cost-benefit analysis of generating electricity from biomass. Energy Policy, 57, 347-354. doi:10.1016/j.enpol.2013.02.005.

Peric, M., Komatina, M., Bugarski, B., \& Antonijevic, D. (2016). Best Practices of Biomass Energy Life Cycle Assessment and Possible Applications in Serbia. Croat. J. For. Eng., 37, 375-390.

Schmidt, J., Leduc, S., Dotzauer, E., Kindermann, G., \& Schmid, E. (2010). Costeffective $\mathrm{CO} 2$ emission reduction through heat, power and biofuel production from woody biomass: A spatially explicit comparison of conversion technologies. Appl. Energy, 87, 2128-2141. doi:10.1016/j.apenergy.2009.11.007.

-Statistical Office of the Republic of Serbia. (2015). Statistical Yearbook of the Republic of Serbia.

Stehlik, P. (2009). Contribution to advances in waste-to-energy technologies. J. Clean. Prod., 17, 919-931. doi:10.1016/j.jclepro.2009.02.011.

Steubing, B., Zah, R., \& Ludwig, C. (2012). Heat, electricity, or transportation? The optimal use of residual and waste biomass in Europe from an environmental perspective. Environ. Sci. Technol., 46(1), 164-71. pmid:22091634 
Stošić I. et al.: Financial Cost-Benefit Analysis of Investment Possibilities in District...

-Tekon-energy. (2011). Pre-feasibility study for application of advanced heat distribution and heat demand management in Bor, Trstenik, Priboj, Majdanpek, Zajecar, Novi Pazar, Nova Varos, Bajina Basta, Kosjeric, and Knjazevac and energy efficiency upgrade of respective district.

Tsai, W. (2012). Regulatory Promotion of Waste Wood Reused as an Energy Source and the Environmental Concerns about Ash Residue in the Industrial Sector of Taiwan. Energies, 5, 4390-4398. doi:10.3390/en5114390.

Vallios, I., Tsoutsos, T., \& Papadakis, G. (2009). Design of biomass district heating systems. Biomass and Bioenergy, 33, 659-678. doi:10.1016/j.biombioe.2008.10.009.

Verani, S., Sperandio, G., Picchio, R., Marchi, E., \& Costa, C. (2015). Sustainability Assessment of a Self-Consumption Wood-Energy Chain on Small Scale for Heat Generation in Central Italy. Energies, 8, 5182-5197. doi:10.3390/en8065182.

Vojinovic, Z. (2016). Renewable Energy Sources and the Possibility of Their Insurance. Econ. Anal., 49, 40-47.

Werner, S., \& Erickson, K. (2015). Three decades of biomass use in Swedish district heating systems. In European Biomass Conference and Exhibition Proceedings. (pp. 519-528). Florence: ETA-Florence Renewable Energies.

Whalley, S., Klein, S.J.W., \& Benjamin, J. (2017). Biomass and Bioenergy Economic analysis of woody biomass supply chain in Maine. Biomass and Bioenergy, 96, 38-49. doi:10.1016/j.biombioe.2016.10.015. 
Stošić I. et al.: Financial Cost-Benefit Analysis of Investment Possibilities in District...

\section{Annex}

\begin{tabular}{|c|c|c|c|c|c|c|c|c|c|}
\hline $\mathrm{O}_{\mathrm{l}}$ & & & & & & & & & in $€$ \\
\hline Items/Years & 1 & 2 & 3 & 4 & 5 & 10 & 15 & 20 & 23 \\
\hline Total Revenues & 0 & 0 & 0 & \begin{tabular}{|l|l|}
4.066 .764 \\
\end{tabular} & 4.250 .077 & 4.814 .935 & \begin{tabular}{|l|l|}
4.943 .058 \\
\end{tabular} & 5.131 .281 & 5.297 .724 \\
\hline Business revenues & 0 & 0 & 0 & 4.066 .764 & 4.250 .077 & 4.814 .935 & 4.943 .058 & 5.131 .281 & 5.297 .724 \\
\hline \multicolumn{10}{|l|}{ Other revenues } \\
\hline Total costs & 2.433 & 9.032 & -125.742 & 1.314 .564 & 1.354 .805 & 1.460 .242 & 1.474 .093 & 1.492 .954 & 1.508 .662 \\
\hline Material costs & 0 & 0 & 0 & 385.797 & 380.916 & 406.577 & 417.891 & 434.087 & 448.130 \\
\hline Costs of biomass purchase for DHC & 0 & 0 & 0 & 256.595 & 252.743 & 266.723 & 270.904 & 279.602 & 288.964 \\
\hline \begin{tabular}{|l|} 
Other material costs \\
\end{tabular} & 0 & 0 & 0 & 129.202 & 128.173 & 139.853 & 146.987 & 154.485 & 159.166 \\
\hline Non-material costs (services...) & 730 & 30.197 & 129.902 & 142.826 & 155.750 & 168.673 & 168.673 & 168.673 & 168.673 \\
\hline Depreciation & 1.703 & 70.460 & 312.031 & 342.186 & 372.341 & $\begin{array}{ll}402.496 \\
\end{array}$ & 402.496 & 402.496 & 402.496 \\
\hline Gross salaries & 0 & 0 & 0 & 432.768 & 432.768 & \begin{tabular}{l|l|l}
432.768 \\
-
\end{tabular} & 432.768 & 432.768 & 432.768 \\
\hline Other costs including effects of energy savings in existing DH systems & 0 & -91.625 & -567.675 & 10.987 & 13.030 & 49.727 & 52.264 & 54.930 & 56.594 \\
\hline Total (total revenues-total costs) & -2.433 & -9.032 & 125.742 & 2.752 .200 & 2.895 .271 & 3.354 .693 & 3.468 .965 & 3.638 .326 & 3.789 .062 \\
\hline
\end{tabular}

Income statement

\begin{tabular}{|c|c|c|c|c|c|c|c|c|c|}
\hline \multicolumn{10}{|l|}{ Income } \\
\hline Items/Years & 1 & 2 & 3 & 4 & 5 & 10 & 15 & 20 & 23 \\
\hline TOTAL REVENUES & 0 & 0 & 0 & 4.066 .764 & 4.250 .077 & 4.814 .935 & 4.943 .058 & 5.131 .281 & 5.297 .724 \\
\hline BUSINESS REVENUES & 0 & 0 & & 4.066 .764 & 4.250 .077 & 4.814 .935 & 4.943 .058 & 5.131 .281 & 5.297 .724 \\
\hline \multicolumn{10}{|l|}{ FINANCIAL REVENUES } \\
\hline \begin{tabular}{|l|} 
TOTAL EXPENSES \\
\end{tabular} & 2.433 & 9.032 & -125.742 & 2.341 .578 & 2.372 .455 & 2.405 .688 & 2.272 .368 & 1.982 .284 & 1.661 .030 \\
\hline BUSINESS EXPENSES & 2.433 & 9.032 & -125.742 & 1.314 .564 & 1.354 .805 & 1.460 .242 & 1.474 .093 & 1.492 .954 & 1.508 .662 \\
\hline Material costs & 0 & 0 & 0 & 385.797 & 380.916 & 406.577 & 417.891 & 434.087 & 448.130 \\
\hline \begin{tabular}{|l} 
Costs of biomass purchase for $\mathrm{DHC}$ \\
\end{tabular} & 0 & 0 & 0 & 256.595 & 252.743 & 266.723 & 270.904 & 279.602 & 288.964 \\
\hline Other material and electricity & 0 & 0 & 0 & 129.202 & 128.173 & 139.853 & 146.987 & 154.485 & 159.166 \\
\hline \begin{tabular}{|l|} 
Non-material costs, maintenance \\
\end{tabular} & 730 & 30.197 & 129.902 & 142.826 & \begin{tabular}{|l|l|}
5 & 155.750 \\
\end{tabular} & 168.673 & 168.673 & 168.673 & 168.673 \\
\hline Depreciation & 1.703 & 70.460 & 312.031 & 342.186 & \begin{tabular}{|l|l|l|}
572.341 \\
\end{tabular} & 402.496 & 402.496 & 402.496 & 402.496 \\
\hline Gross salaries & 0 & 0 & 0 & 432.768 & \begin{tabular}{l|l}
8 & 432.768 \\
\end{tabular} & 432.768 & 432.768 & \begin{tabular}{l|l}
3 & 432.768 \\
\end{tabular} & 432.768 \\
\hline Other expenses and effects of investments in energy savings of existing DH & 0 & -91.625 & -567.675 & 10.987 & 13.030 & 49.727 & 52.264 & 54.930 & 56.594 \\
\hline FINANCIAL EXPENSES & 0 & 0 & & 1.027 .014 & 1.017 .650 & 945.446 & 798.275 & 489.329 & 152.368 \\
\hline PROFIT BEFORE TAX/LOSS & -2.433 & -9.032 & 125.742 & 1.725 .186 & 1.877 .622 & 2.409 .247 & 2.670 .690 & 3.148 .997 & 3.636 .694 \\
\hline Tax on profit & 0 & 0 & 12.574 & 172.519 & 187.762 & 240.925 & 267.069 & 314.900 & 363.669 \\
\hline NET PROFIT/LOSS & -2.433 & -9.032 & 113.168 & 1.552 .667 & 1.689 .859 & 2.168 .322 & 2.403 .621 & 2.834 .097 & 3.273 .024 \\
\hline
\end{tabular}

\begin{tabular}{|c|c|c|c|c|c|c|c|c|c|}
\hline Cash flow for liquidity calculation & & & & & & & & & in $€$ \\
\hline Items/Years & 1 & 2 & 3 & 4 & 5 & 10 & 15 & 20 & 23 \\
\hline INFLOW & 24.469 & 987.978 & 3.938 .639 & 4.861 .555 & \begin{tabular}{|l|}
4.699 .672 \\
\end{tabular} & 4.814 .935 & 4.943 .058 & 5.131.281 & 6.209 .749 \\
\hline Revenues & 0 & 0 & 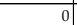 & 4.066 .764 & 4.250 .077 & 4.814 .935 & 4.943 .058 & 5.131 .281 & 5.297 .724 \\
\hline Loans & 0 & 0 & 0 & 0 & 0 & 0 & 0 & 0 & 0 \\
\hline Sources of finance & 24.469 & \begin{tabular}{c|c|}
987.978 \\
\end{tabular} & 3.938 .639 & 794.791 & 449.595 & 0 & 0 & 0 & 0 \\
\hline Residual value & 0 & 0 & 7 & 0 & 0 & 0 & 0 & 0 & 912.025 \\
\hline OUTFLOW & 25.199 & 926.550 & 3.598 .316 & 4.198 .990 & 3.982 .018 & 4.021 .923 & 4.238 .506 & \begin{tabular}{|c|}
4.630 .567 \\
\end{tabular} & 5.024 .385 \\
\hline Investments & 24.469 & 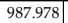 & 3.938 .639 & 794.791 & 449.595 & 2.211 & 2.323 & 4.834 & 4.981 \\
\hline Material costs & 0 & 0 & 0 & 385.797 & 380.916 & 406.577 & 417.891 & 434.087 & 448.130 \\
\hline Non-material costs, maintenance & 730 & 30.197 & 129.902 & 142.826 & 155.750 & 168.673 & 168.673 & 168.673 & 168.673 \\
\hline \begin{tabular}{|l|} 
Gross salaries \\
\end{tabular} & 0 & 0 & 0 & 432.768 & 432.768 & 432.768 & 432.768 & 432.768 & 432.768 \\
\hline Other expenses and effects of investments in energy savings of existing DH & 0 & -91.625 & -567.675 & 10.987 & 13.030 & 49.727 & 52.264 & 54.930 & 56.594 \\
\hline Loan reimbursement and interests & 0 & 0 & 0 & 1.094 .801 & 1.094 .801 & 1.094 .801 & 1.094 .801 & 1.094 .801 & 1.094 .801 \\
\hline Tax on profit & 0 & 0 & 12.574 & 172.519 & 187.762 & 240.925 & 267.069 & 314.900 & 363.669 \\
\hline Share for Investor & 0 & 0 & 84.876 & 1.164 .501 & 1.267 .395 & 1.626 .241 & 1.802 .716 & 2.125 .573 & 2.454 .768 \\
\hline NET CASH FLOW (I-II) & -730 & 61.428 & 340.323 & 662.565 & 717.654 & 793.011 & 704.552 & 500.714 & 1.185 .363 \\
\hline
\end{tabular}

Cash flow for NPV and FRR calculation

\begin{tabular}{|c|c|c|c|c|c|c|c|c|c|}
\hline Jtemo $/ Y_{\text {eare }}$ & & & & & & & & & \\
\hline Items/Years & 1 & 2 & 3 & 4 & 5 & 10 & 15 & 20 & 23 \\
\hline INFLOW & 0 & 0 & & | 4.066.764 & $\mid 4.250 .077$ & $\mid 4.814 .935$ & $\mid 4.943 .058 \mathrm{~g}^{\mathrm{5}}$ & 5.131.281 & 6.209 .749 \\
\hline Revenues & 0 & 0 & & 4.066 .764 & 4.250 .077 & 4 4.814.935 & 4.943 .0585 & 5.131.281 & 5.297 .724 \\
\hline Residual value & 0 & 0 & 0 & 0 & 0 & 0 & 0 & & 912.025 \\
\hline OUTFLOW & 25.199 & 926.550 & 3.598 .316 & \begin{tabular}{|c|}
3.104 .188 \\
\end{tabular} & 2.887 .216 & 2.927 .122 & 3.143 .705 & 3.535 .765 & 3.929 .584 \\
\hline Investments & 24.469 & 987.978 & 3.938 .639 & 794.791 & 449.595 & 2.211 & 2.323 & 4.834 & 4.981 \\
\hline Material costs & 0 & 0 & 0 & 385.797 & 380.916 & 406.577 & 417.891 & 434.087 & 448.130 \\
\hline Non-material costs, maintenance & 730 & 30.197 & 129.902 & 142.826 & 155.750 & 168.673 & 168.673 & 168.673 & 168.673 \\
\hline Gross salaries & 0 & 0 & & 432.768 & 432.768 & 432.768 & 432.768 & 432.768 & 432.768 \\
\hline Other expenses and effects of investments in energy savings of existing DH & 0 & -91.625 & -567.675 & 10.987 & 13.030 & 49.727 & 52.264 & 54.930 & 56.594 \\
\hline Tax on profit & 0 & 0 & 12.574 & 172.519 & 187.762 & 240.925 & 267.069 & 314.900 & 363.669 \\
\hline Share for Investor & 0 & 0 & 84.876 & 1.164 .501 & 1.267 .395 & 1.626 .241 & 1.802 .716 & 2.125 .573 & 2.454 .768 \\
\hline NET INFLOW (I-II) & -25.199 & -926.550 & -3.598 .316 & 962.575 & 1.362 .860 & $\mid 1.887 .813$ & 1.799 .353 & 1.595 .516 (1) & 2.280 .165 \\
\hline
\end{tabular}

